\title{
EVALUATION OF ACADEMIC RESEARCH PRODUCTIVITY: NECESSITY FOR, \\ SOME METHODS AND INDICATORS OF PRODUCTIVITY
}

\author{
H. A. Labuschagne
}

Bureau for Research, PU for CHE

\section{ABSTRACT}

The extent of funds invested in research and the increasing dependency of society on research evoke public interest to which politicians have to listen. These aspects compel universities to consider evaluation of their research performance, because enquiries are made about effective, efficient and accountable application of research funds. These qualities are reflected in research performance. Various sources, however, reveal that there is little attempt by universities to evaluate such performance.

Several approaches to the evaluation of research have been suggested. The most objective and generally accepted method is citation analysis. Other indicators of research performance are peer and bibliometric evaluation, election to an office of a professional association, success in raising research funds and invitations to read scientific papers.

It is intended to compile a balanced inventory of indicators of academic research performance and to classify related phenomena in various value indices. Such an approach can supply university management with a method of measuring their research output for performance improvement.

\section{INTRODUCTION}

The philosophy of life of a university is an important factor in appointing and evaluating staff members. Criteria arising from such a philosophy may vary from university to university. At the Potchefstroom University for Christian Higher Education, practising science from a Calvinist point of view is an important criterion. At another university it may bear no value. Against the above Christian approach and the biblical demand that Koers 53(4) 1988 $-568-$ 
man shall labour in cultivating and guarding the earth, the University is justified in expecting a full day's productive labour from its employees. Therefore, the University may assess the extent of their productivity. However, the University must enable its staff members to perform their duties by supplying the necessary opportunity, infrastructure and funds. ${ }^{1}$

University autonomy, on the other hand, does not excuse a university from public demands for sound operation. Each university in the Republic of South Africa has been established by Act of Parliament. There is also a general Act applicable to all universities (Labuschagne, $1982: 28-30$ ). Within the limits of statutory provisions, universities are as autonomous as the extent of their dependence on government subsidy allows them to be. ${ }^{2}$ This limitation on university autonomy does not only apply to freedom of thought, education and research, but includes the

1 It is the Potchefstroom University's policy to assist young researchers financialiy to a level where he/she can successfully compete for research funds from statutory research councils. Financial assistance is rendered in a number of ways viz.

- out of departmental funds:

- faculty research committees who consider grants from the subsidised research fund;

- grants out of deans' funds;

- the Committee for Foreign Affairs, which considers grants for research, study and attending of conferences abroad; and

- conditions of service which provide for paid long leave.

2 About 668 of the Potchefstroom University's income for $1987 / 1988$ derived from government subsidy. 
way it spends funds from government sources. In a recent report the Committee of University Principals found it necessary to advise universities to execute their autonomy with responsibility and selfdiscipline. They were also urged to acknowledge the limits on their decisionmaking authority (Komitee van Universiteitshoofde, 1987:1-2).

In addition to the above political interest in university affairs, scientific research at universities is arousing public concern world wide, because it has become expensive and is competing for funds with public services such as health and security. The taxpayer claims accountability from the government for the spending of government funds at universities. The community queries the universities' ability to graduate students and produce research results costeffectively.

Furthermore, community life is confronted by enormous issues and has become dependent upon research for solutions. The search for alternative energy resources and the threat of AIDS are two examples. Thus the responsibility of spending uriversity research funds efficiently has become a vital international issue.

In Europe and Britain authorities endeavour to phase out disciplines at universities if academics fail to satisfy research demands. In South Africa the Foundation for Research Development has instituted a research funding scheme according to which only academic researchers who have achieved specific standards receive financial aid. The Department of National Education considers subsidy only on research output which complies with specified international standards. Pressure from the community, the government and funding bodies on research institutions for professional management to enhance greater efficiency is mounting. The critical review of academic research productivity is therefore an urgent requirement - and yet it would seem as if the councils and senates of universities in South Africa have not yet embarked on formal assessment endeavours.

Against this background and the premises that performance assessment is Christianly justified and that there are limits to university autonomy, the purpose of this paper is to focus attention on the necessity to assess academic research productivity, to discuss a few methods as to how this $-570-$ 
can be achieved, and to point out a few indicators of research productivity. It is also intended to stimulate thinking, and to raise questions concerning the honest employment of labour, funds and material on research activities.

\section{NECESSITY FOR EVALUATING RESEARCH PRODUCTIVITY}

Effectiveness, efficiency and public accountability are of paramount importance for research management. In the present severe financial contraints on universities worldwide, it can be assumed that the universities' central managements will accept the above qualities as objectives for research management performance. But then such performance must be evaluated to establish whether resources have been utilized effectively and efficiently.

Effectiveness of action refers to the extent to which objectives have been attained. Efficiency is concerned with the care of applying limited resources to attain objectives. Public accountability requires that the actions of public functionaries can be examined in public.

\subsection{External expectations}

Universities established and functioning under acts of government and financed largely by public funds have to be classified as public institutions. They are thus subject to public accountability. Members of the public and politicians have for the above reasons every right to enquire whether research funds are being applied effectively and efficiently.

In OECD-countries great pressure is being placed on research institutions by governments for the establishment of efficient research structures and activities (Irvine, Martin \& Oldham, 1983:1). In the USA concern about university spending had as far back as 1973 already led to public insistence on the evaluation of university activities (Segerstedt, 1973:179). In South Africa research productivity is being looked at more closely by the government, because the new subsidy formula for universities places the stress on research outputs (South Africa (Republic), 1982:41). 
The growing public interest in research is concerned with the safeguarding and promotion of the general welfare. It requires that research should be undertaken on the widest possible range of community issues. However, research is expensive because it requires expensive equipment and highly qualified personnel.

Furthermore, research also has to compete with essential public services such as welfare, national security, health and education for slices of the limited resources. The greater competition among the various interests leads to the situation where the research community has to account for the use of research funds by objective evaluation to justify the research successes or failures.

\subsection{Internal reaction}

A university is an institution for higher education with the purpose of practising sciences at the tertiary level. As such the university offers a physical, social and psychological environment as well as educational services in which the processes of learning and generation of knowledge can flourish. Thus, "... the institution, to justify its existence, must evaluate its effectiveness in producing the desired results and its efficiency in utilizing resources to do so" (Knowles, 1970:2-54). However, this does not seem to have happened as far as evaluation of research productivity is concerned.

In a study on the evaluation of research in British science in 1983 it was found that there had been little attempt by the universities' central managements to evaluate research performance. Heads of departments endeavour to establish the research performance of their staff in order to form a general impression and to distribute resources accordingly (Irvine et al., 1983:24-25). In South Africa the funds spent on research over a certain period have generally been regarded as an indication of research output, on the assumption that benefits equalled costs in research (South Africa (Republic), 1982:41). A survey at South African universities under the auspices of the Department of National Education in 1982 reflected a vague, unstructured and sporadic approach to research performance evaluation. An empirical investigation at Potchefstroom University in 1985 confirmed the above survey. The absence of -572 - 
a formal scheme approved by the university council or senate by which to assess research performance raises questions on effective, efficient and accountable application of research funds. Thus the observation in the British Green Paper: "We have evidence that the universities' accountability is not being responsibly exercised", can be appreciated (Hoggart, 1985:292).

In order to reply rationally to critical questions universities in South Africa will have to implement their own research evaluation schemes. If not, the government may consider a step which may be as academically unacceptable as in the United Kingdom. The University Grants Committee in Britain announced in May 1986 "... the results of its attempt to evaluate the research performance of university departments ... The UGC's ratings are now being used as one of the criteria for the distribution of resources between and within universities ... fundamental methodological errors have been identified in the design of the UGC's exercise. These included: (1) a failure to undertake a comprehensive analysis of perhaps the most valid and direct indicator of research performance, namely, actual research output; (2) sampling artefacts in the design which contributed to a pronounced bias in favour of larger departments; (3) the use of measures of suspect validity (for example, research income) which are known to be strongly confounded by factors unrelated to research performance" (Gillett, 1987:59).

\section{METHODS FOR EVALUATING RESEARCH PRODUCTIVITY}

The complexity of assessing productivity of researchers is illustrated by questions such as: what should a researcher achieve to be regarded as being productive, how can one distinguish between above-average and average researchers and should a researcher be measured in accordance with his contributions to the scientific field, of his contributions to his institutions' achievements, or both? (Edwards \& McCarrey, 1973:34).

Various efforts towards the meaningful assessment of research productivity have been made, amongst others with the use of mathematical, statistical and computer aids (Tauss, 1975:13). Other methods are the judgment of peers, bibliometric indicators and a combination of the above two (Irvine et al., 1983:3-7). 
Friedlander applied factoranalytical techniques with ten achievement criteria to distinguish groups of researchers. He found that it is potentially prejudicial and misleading to use only one criterion for the evaluation of all scientists. According to him few multi-criteria studies have been done, and there is an indication that such an approach will yield more reliable results in the efforts to determine research achievement (Edwards \& McCarrey, 1973:39). Irvine et al. (1983:7-8) came to a similar finding.

Lopez offers an evaluation method with the approach of observing specific phenomena, a suitable method to distinguish between phenomena and expression of the phenomena in terms of numerical values (Lopez, 1968: 170-173). In the following paragraphs such phenomena, which seem to be widely acceptable, will be discussed briefly.

\section{INDICATORS OF RESEARCH PRODUCTIVITY}

Because of the diversity and some times intangible nature of research products, Martin $\varepsilon$ Irvine maintain that "... no comprehensive and unitary quantification of achievements of basic science is possible" (Martin $\varepsilon$ Irvine, 1981:412). However, research productivity could be evaluated with techniques such as peer evaluation, bibliometric evaluation and citation analysis (Irvine et al., 1983:3-8).

\subsection{Peer evaluation as an indicator of research productivity}

Peer evaluation involves the evaluation of a scientist's work for a specific purpose by other scientists who work in the same or related fields.

Motives for peer evaluation include gaining an independent and unbiased judgement of the scientific quality of research contributions; considering arguments for or against continued financial support for research programmes; allocating funds to various new research projects; determining research priorities; and offering a judgement on the measure of success of individuals or groups as scientists.

Advantages of peer evaluation are that it is relatively inexpensive and can be done expeditiously; it does not make excessive demands on peers and specific norms can be set and maintained; it is the best mechanism $-574-$ 
to divide research funds, to monitor research and to evaluate research results. On the other hand peer evaluation can usually be applied successfully in one field but problems occur when evaluative reports have to be used as comparative norms between different fields of study. The danger also exists that evaluation can be coloured by the evaluator's group interests or school of thought (Irvine et al., 1983:4). There is also an unavoidable tendency among scientists to weigh up the value of scientific contributions in comparison with their own research interests and activities, or to value contributions highly because of a relationship with a successful group or university of renown. Finally, a good "advocate" can swing the result of an issue in the favour of his cause, and peer groups can tend to apply double standards between various disciplines or groups (Martin \& Irvine, 1983:73).

Peer evaluation is, as a result of the foregoing disadvantages, not an undisputed criterion for scientific achievement but at most a supplementary criterion.

\subsection{Bibliometric evaluation as an indicator of research productivity}

A scientist's written work is-the most important and the most general proof of his productivity, because it is visible and the researcher's most important instrument through which new ideas and results can be disseminated to other scientists (Irvine \& Martin, 1983:64) and the number of publications can indicate scientific activity (Carpernter $\varepsilon$ Narin., 1981:430). However, it is questionable what is measured by the quantity of publications, because even if this should indicate to a reasonable extent research productivity, the significance as scientific contribution is still uncertain. Some researchers have found that there is a correlation between the number of publications and the quality of these, while others have found that there is no correlation at all (Martin E Irvine, 1983:65-66). The problem is that various publications differ in their contributory value to science. Another method used to gain an indication of quality of publication is citation analysis, discussed below. 


\subsection{Reference to scientific publications (citation analysis)}

Another meaningful indicator of research productivity is the number of times the work of a researcher is referred to in the research publications of other researchers. The number of citations can be quantified and there are extensive data banks for that purpose. As the number of publications can be an indication of the quantity of a researcher's work, so citation analysis can provide an indicator of the quality of a researcher's work and the scientific impact that he is making (Irvine et al., 1983:6-7). According to Edwards and McCarrey a count of references such as those revealed in Science Citation Index (SCI) is the most general and the most objective method of gaining a qualitative indication of scientific achievement.

The point of departure for such an approach is that there is a high positive correlation between the number of citations and the quality of the research described in the relevant article (Edwards $\&$ McCarrey, 1973:37). There is, however, a diffe,ence in quality, in importance and in impact of a publication which must be observed in order to establish the full significance of citations.

Quality refers to research characteristics such as lack of visible errors, originality of modus operandi and conclusions and creative and critical thinking.

The importance of a publication refers to its potential influence on related research activities such as the promotion of scientific knowledge whereas impact is the real influence it has at a given time. "... a paper creating a great impact represents a major contribution to knowledge at that time (although its impact may ... alter with time)" (Martin \& Irvine, 1983:70).

\subsection{Other indicators of research productivity}

Honorary awards on the basis of research achievements can also serve as indicators to research productivity. Irvine et al. (1983:5-6) mention, in this regard, prizes, medals and honorary degrees. Other indicators of research productivity are: formal acknowledgements, such as election to an office, for example as president of a professional association; $-576-$ 
success in raising research funds and invitations to read papers at scientific conferences.

Acknowledgement which scientists have gained for the above achievements have the advantage that it has already been evaluated by peers.

No single indicator of research productivity discussed so far can be applied in isolation. They are all contributory factors in assessing research productivity as every one illuminates different aspects of the comprehensive function of research.

\section{RECAPITULATION}

A further investigation to design an aid in evaluating academic research productivity is under way, the approach being to observe a comprehensive inventory of academic research products, to classify related phenomena in various indices and to attach numerical or symbol values to each index.

\section{BIBLIOGRAPHY}

CARPENTER, M.P. \& NARIN, F. 1981. The adequacy of the science citation index $(\mathrm{SCl})$ as an indicator of international scientific activity. Journal of the American Society for information science : 430-439, November.

EDWARDS, S.A. \& MCCARREY, M.W. 1973. Measuring the performance of researchers. The international journal of research management, $X V I(1): 34-41$, January.

GILLETT, R. 1987. The University Grants Committee's assessment of departments was fundamentally flawed. New Scientist : 59-60, July.

HOGGART, R. 1985. What price selfgovernment. Universities Quarterly: Culture, education $\&$ society. 39(4):290-292, Autumn. 
IRVINE, J. \& MARTIN, B.R. 1983. Assessing basic research: the case of the Isaac Newton telescope. Social studies of science: 13:49-86.

IRVINE, J., MARTIN, B. \& OLDHAM, G. 1983. Research Evaluation in British Science: a SPRU review, Sussex: University of Sussex, Unpublished report. $30 \mathrm{p}$.

KNOWLES, A.S., ed. 1970. Handbook of college and university administration: academic. New York : McGraw-Hill.

KOMITEE VAN UNIVERSITEITSHOOFDE. 1987. Verslag van die Hoofkomitee van die KUH-ondersoek na makro-aspekte van die universiteitswese binne die tersière onderwysverband in die RSA. Pretoria : Komitee van Universiteitshoofde. $135 \mathrm{p}$.

LABUSCHAGNE, H.A. 1982. Administrasie van navorsing aan geselekteerde Suid-Afrikaanse Universiteite met spesifieke verwysing na beleidbepaling, organisering en finansiering. Pretoria. 256 p. (Proefskrif (D.Litt. et Phil.) - Universiteit van Suid-Afrika.)

LOPEZ, F.M. 1968. Evaluating employee performance. Chicago: Public Personnel Association. $306 \mathrm{p}$.

MARTIN, B.R. \& IRVINE, J. 1983. Assessing basic research: some partial indicators of scientific progress in radio astronomy. Research policy: a journal devoted to research policy, research management and planning, 12(2):61-90, April.

MARTIN, B.R. \& IRVINE, J. 1981. Internal criteria for scientific choice: an evaluation of research in high-energy physics using electron accelerators. Minerva, $X I X(3): 408-432$, Autumn.

SEGERSTEDT, T. 1973. A systematic approach to research evaluation. Social Science Information, 12(1):179-185.

SOUTH AFRICA (REPUBLIC). Department of National Education. 1982. An investigation of government financing of universities: Report SAPSE-110. Pretoria : Staatsdrukker. $102 \mathrm{p}$.

-578 - 
TAUSS, K.H. 1975. A pragmatic approach to evaluating $R \& D$ programs. The international journal of research management, XVIII(5):13-15, September. 